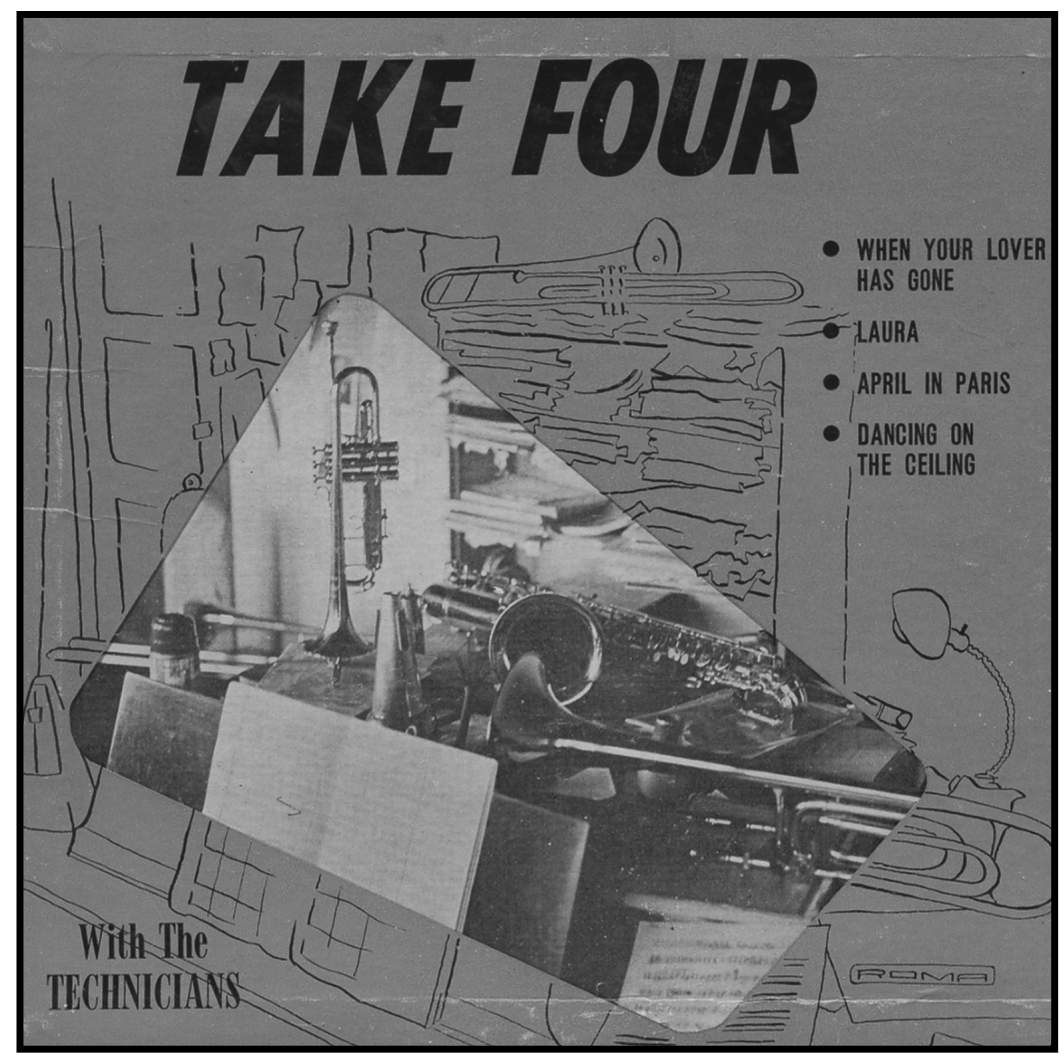

\title{
TUNING UP WITH A FEW INTRODUCTORY NOTES
}

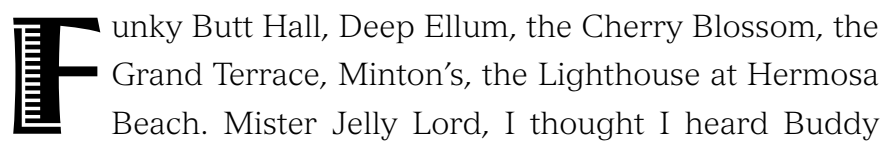

Bolden say, Open up that window and let the bad air out. $\mathrm{O}$ play that thing! Hello Central, give me Doctor Jazz, he's got what I need, I know he has. Struttin' with some barbecue. I'm coming Virginia. It don't mean a thing if it ain't got that swing. Born in Texas, raised in Tennessee, no one woman's gonna make a fat mouth outta me. I'd rather drink muddy water, live in a log, than be up here in New York treated like a dirty dog. Mercy. Your feet's too big. Hey Charlie, let's play the blues in B. I'm gonna move way out on the outskirts of 
town; don't want that iceman comin' round. Salt peanuts, salt peanuts, ooh bop shebam. Freedom's the shape of jazz to come.

These legendary places, names, lines from lyrics, and song and record titles are, for those who know the story of jazz, some of the music's most famous historical touchstones, among which are those connected with Elm Street in Dallas and with native Texas musicians Jack Teagarden, Charlie Christian, and Ornette Coleman. Concerned with these and other celebrated moments and figures in the history of jazz, the present gathering of articles, book-review essays, talks, and ruminations expands on and adds to my book Texan Jazz, published by the University of Texas Press in 1996. Although the sixteen pieces collected here were written during a fourteen-year period, from 1992 to 2005, they represent but a fraction of the time that I have been fascinated by jazz. My love for the music began over fifty years ago in 1954, when, as a sophomore, I formed part of the dance band at Beaumont's South Park High School. In that year I purchased my first jazz recordings in local shops and learned something about the early periods of the music, especially the work of Jelly Roll Morton and Duke Ellington from the 1920s and 1930s. In 1955 I heard recordings by the great Charlie Parker, who, without my being aware of the fact, would die during that same year at the age of thirty-five. At the time I could hardly have imagined that I would spend the rest of my life listening to, rejoicing in, and marveling at a music that has become for me an endless source of aural pleasure, historical and cultural insights, and even regional pride, once I discovered the many Texans who were crucial to the creation of this art form admired around the globe.

Shortly after publication of Texan Jazz, I was invited by Norbert Carnovale to contribute one of six projected volumes in a series on jazz that he was editing for Greenwood Press of Connecticut. I had been recommended to this general editor by Dr. Richard Burkart, my college trumpet instructor, to whom I am indebted not only for making possible the writing and publication of my second book on jazz, The Early Swing Era, 1930 to 1941, but also for having introduced me to the music of Count Basie, Miles Davis, and Les Brown when, in 1957-1958, I became a member of the Technicians, the dance band that Dr. Burkart directed at

PREVIOUS PAGE: Album jacket of 45 rpm record album produced in 1958 by Professor Richard Burkart and his then Lamar State College of Technology Technicians. Line drawings by Roma Newton. Reproduced by permission of Richard Burkart. 
Beaumont's then Lamar State College of Technology. Prior to my college career, it had been my high school orchestra teacher, Harold Meehan, who had first opened me up to the panorama of jazz with its invigorating rhythms, tonal richness, and complex system of improvisation. Almost from the beginning of my jazz education, I was aware that Texans had been active at high levels in the music's history, including Beaumont's own Harry James, a star trumpeter of the Benny Goodman Orchestra. In fact, I learned early on that the James home had been moved from downtown Beaumont to Florida Street, the very street on which I lived when I first began to listen to jazz. Coincidentally, the first important album that I acquired, entitled I Like Jazz, contained an impressive example of James's trumpet virtuosity: his solo on the 1937 Goodman radio broadcast of "Jam Session." Also in high school I discovered that multi-reedman Jimmy Giuffre was a native of Dallas, this after having heard him on a number of albums participating as a key member of the group known as Shorty Rogers and His Giants. While still in high school I was fortunate enough to hear Dr. Burkart's Lamar Tech jazz octet perform several of the pieces that had been recorded by the Giants, two of which, "The Pesky Serpent" and "Indian Club," were composed by Giuffre. Later in the early 1960s I would encounter the music of other Texas jazzmen, among them Vernon's Jack Teagarden and Fort Worth's Ornette Coleman. It was this early exposure to Texans in jazz that eventually led me to write Texan Jazz.

But the publication of my first book would by no means signal the end of my jazz education in terms of a Texas contribution. Even though my second book was devoted primarily to non-Texas musicians of the swing era, in researching that volume I unearthed a number of native Texas jazzmen whose work I had overlooked in writing Texan Jazz. One example was a Beaumont-born drummer, Oliver Coleman, who in the late 1930s was an outstanding member of the Earl Hines Orchestra. Even though I discussed Coleman's work in The Early Swing Era, I remained unaware that he was a Texan until after the book was published. On the other hand, I did discover at the time of writing this second book that I had left out of Texan Jazz multi-reedman Clarence Hutchenrider from Waco, who was an important member of the Casa Loma Orchestra throughout the 1930s. Later, in “The Roots of Texan Jazz," I would cover the career of Hutchenrider, as well as that of cornetist Tom Howell of Cameron, also discovered after the publication of Texan Jazz. Thus, each of the essays in the present collection examines further the important 
roles played by Texans in jazz history. Even after more than fifty years I find that I am far from exhausting this captivating subject. Indeed, the essays collected here strike me as having but inaugurated an investigation into this unlimited field of study. One wish that I have for this selection of essays is that it may encourage others to explore Texan jazz in new areas and from new perspectives.

Today I can recognize the potential for future articles and books on Texans in jazz primarily because the high school and college that I attended in Beaumont permitted the teaching of jazz as a legitimate part of the educational curriculum. Without my understanding it at the time, my high school and college teachers were preparing me for a lifetime of enrichment, both in terms of aesthetic enjoyment and of a growing knowledge of the significant position occupied by jazz in the history of the nation, and even the world. Although native pride may not have been a lesson that my teachers tried to instill in me as one of the values of learning about jazz through listening to and trying to perform the music, being able to identify Texas musicians_-and even a folklorist like Austin's Alan Lomax-as significant figures in its creative and critical record was yet another benefit accruing from my early instruction in the history of jazz.

One professional consequence of my introduction to jazz over a halfcentury ago is the great satisfaction that I now take in sharing my enthusiasm for this music with new generations of students. For several years I have had the privilege of teaching, at the University of Texas at Austin, a freshman seminar on Jazz and Literature. Although the field of my degrees is not music but literature, I have long cultivated an interest in the relationship between the two art forms. A number of world-class writers of poems, short stories, novels, and plays have created works based on the lives of jazz musicians, the impact of the music itself, or its symbolic meaning in terms of ideas of freedom, hero worship, and integration. In conjunction with reading such works of literature, as well as biographies and autobiographies of the musicians, my students listen to jazz and discover the musical and extramusical meanings that the writers on jazz have heard in live or recorded performances, have observed in seeing the musicians play, sing, and interact with their fellows, and have described in such revelatory and stimulating poetry and prose.

The essay-review included here on Alfred Appel's book Jazz Modernism reveals among critics and commentators a growing awareness of the links between jazz and the twentieth-century movements of 
modernism and postmodernism in world art and literature. Once again, Texans, as musicians, authors, and artists, have figured significantly in the connections created and observed between jazz, art, and literature, including, for example, trombonist Jack Teagarden, writer Donald Barthelme, and painter Robert Rauschenberg. The aesthetic, cultural, and historical reach of jazz has truly been global in its impact and appeal, and this fact makes the inclusion of jazz studies in public schools and higher education a valid and commendable development. It is of course ironic that this music, which was originally denigrated and even condemned for its wicked origins and for being a crude, corrupting influence on youth, has proven one of the most respected products of American civilization. Personally I am eternally grateful to my schools and teachers for having brought this music and its legacy to my attention during the formative years of my education. I am hopeful that these sixteen essays will help to bring an appreciation for jazz-its cultural and historical dimensions as well as its Texas connections-to all those with ears to hear and hearts and minds willing to experience the allure of this enduring music. 
THIS PAGE INTENTIONALLY LEFT BLANK 
JAZZ MAVERICKS OF THE LONE STAR STATE 
THIS PAGE INTENTIONALLY LEFT BLANK 